\title{
Stem cell apoptosis in HIV-1 alopecia
}

Background: Diffuse alopecia occurs in almost $7 \%$ of HIV-1-infected patients. Telogen effluvium is the main pathogenic mechanism involved. Apoptotic keratinocytes in the outer root sheath at bulge level was described as the most characteristic histopathologic finding of this kind of hair loss.

Methods: A case--control study was conducted to investigate the occurrence of apoptosis of follicular stem cells at the bulge in diffuse alopecia of HIV-1 infection. We applied a double-staining procedure to transverse scalp sections from $15 \mathrm{HIV}$-1-infected patients and 12 controls, with the monoclonal antibody anticytokeratin 19 as stem cell marker and TUNEL technique to identify apoptosis.

Results: Eighty percent of cases and $25 \%$ of controls presented at least one double-stained follicle. The proportion of positive follicles per section was $48 \%( \pm 7 \%)$ for cases and $26 \%( \pm 13 \%)$ for controls.

Conclusion: Our study demonstrated that diffuse alopecia related to HIV-1 infection represents a hair cycle disturbance and that part of the follicular stem cell population become apoptotic in a higher proportion than normal subjects. We found no cytotoxic folliculitis. Owing to its cell-cycle interaction and caspase-induction capacities, we propose HIV-1 viral protein $\mathrm{R}$ as a possible follicular stem cell apoptosis inductor.

Barcaui CB, Gonçalves da Silva AM, Sotto MN, Genser B. Stem cell apoptosis in HIV-1 alopecia.

J Cutan Pathol 2006; 33: 667-671. (C) Blackwell Munksgaard 2006.

\section{Carlos Baptista Barcaui ${ }^{1}$, Ana Maria Gonçalves da Silva², Mírian N. Sotto ${ }^{1}$ and Bernd Genser $^{3}$}

${ }^{1}$ University of São Paulo Medical School, ${ }^{2}$ Tropical Medicine Institute of São Paulo, São Paulo, and

${ }^{3}$ Public Health Institute, Federal University of Bahia, Bahia, Brazil
Carlos Baptista Barcaui MD, MSc, Praça Antônio Callado, 175/1804, Rio de Janeiro 22793-081, Brazil

Tel: +55 2133283752

Fax: +55 2133283752

e-mail: cbarcaui@cliderma.com.br

Accepted for publication September 28, 2005
Highly active antiretroviral therapy (HAART) has substantially modified the expectation of life of HIV1 -infected individuals and is responsible for a change in the morbidity of cutaneous diseases. ${ }^{1}$ Among dermatological disorders, alopecia occurs in almost $7 \%$ of those patients. ${ }^{2}$ Despite being an esthetic issue, hair loss has a very negative influence on the patients self-image and quality of life. ${ }^{3}$ Telogen effluvium is the main pathogenic mechanism involved in hair loss, and the causes are many: immunological disturbances, endocrinological dysregulation, nutritional deficiencies, drugs, acute and chronic systemic infections, and others.

A tightly controlled balance of proliferation, differentiation, and apoptosis characterizes hair follicle morphogenesis and cycling. The catagen regression is driven by massive apoptosis of hair bulb keratinocytes. Multiple factors are involved in the control of catagen apoptosis such as Fas, TGF- $\beta$, TNF- $\alpha$, FGF-5, IGF-1, PTHrp, neurotrophins, and others. ${ }^{5}$ Recently, it was demonstrated that clusters of
TUNEL-positive cells (apoptotic cells) were present in the isthmus/bulge, where follicular stem cells are situated, during the catagen phase, indicating that a subpopulation of bulge cells is not permanent. ${ }^{6-8}$ Furthermore, bulge cells undergo apoptosis after mechanical depilation and are replaced by secondary germ cells. ${ }^{9}$

Smith et al. ${ }^{4}$ described apoptotic keratinocytes in the outer root sheath at the bulge level as the most characteristic histopathologic finding in HIV-1 diffuse alopecia. This is also the site where apoptotic keratinocytes are seen in graft vs. host disease $(\text { GVHD })^{10,11}$ in which the stem cells are the prime target. They hypothesized that an autoimmune (GVHD-like) reaction could play a role on the pathogenesis of HIV-1 disease including hair loss.

The aim of the study described in this paper was to characterize the histological pattern and to investigate the occurrence of apoptosis of the follicular stem cells at the bulge, in diffuse non-cicatricial alopecia of HIV-1 infection. 


\section{Barcaui et al.}

\section{Materials and methods}

The casuistic of this case-control study consisted of 15 HIV-1-seropositive patients with diffuse noncicatricial alopecia, seven males and eight females, aged $22-42$ years $($ mean $=35.3 \pm 6.5$ ), and CD4 cell count ranging from 66 to $601 \mathrm{cells} / \mathrm{mm}^{3}$ $($ mean $=302.7 \pm 134.5)$, with no other systemic infection or endocrinological disturbance, were submitted to scalp biopsy of the occipital region with a 4-mm punch. This area was selected to avoid initial pattern alopecia misdiagnose. During their regular visit, patients were asked about hair disorders. Patients who presented a volume reduction and/or texture change of the scalp hairs were included in the study. All patients were subjected to clinical examination in order to exclude other hair conditions such as cicatricial alopecia, androgenetic alopecia, traction alopecia, tricotillomania, alopecia areata, and acute telogen effluvium. Twelve healthy volunteer subjects, five males and seven females, of ages ranging from 25 to 64 years old (mean $=34 \pm 11.0$ ) without alopecia, were chosen as controls.

The scalp samples were fixed in 10\% buffered formalin solution, horizontally sectioned according to Headginton's technique, ${ }^{12}$ and paraffin embedded, with the freshly cut surfaces down in the block.

Evaluation of the histological morphometric analysis included the total number of follicular units, the total number of follicles (anagen, telogen, and catagen; velus and terminal types), total number of follicular stela (residual fibrous tracts), and terminal germinal units. Specimens were stained through the Gomori's method.

To investigate stem cell apoptosis in the bulge, we performed a double-staining technique with deoxynucleotidyl transferase-mediated deoxyuridine triphosphate nick-end (TUNEL), which delineates single cells with fragmented DNA and anticytokeratin 19 antibody (CK19), as a stem cell marker. ${ }^{13-15}$ The number of follicles presenting double-staining positive cells at the bulge level in each section was achieved. Sections presenting at least one doublestained follicle were considered positive.

Paraffin sections mounted onto 3-amino-propyltriethoxy-silane (cod. A3648, Sigma Chemical, St Louis, MO, USA)-coated glass slides were deparaffinized in xylene, rehydrated, and rinsed in phosphate-buffered saline (PBS), $\mathrm{pH}$ 7.4. Sections were treated with proteinase $\mathrm{K}(20 \mu \mathrm{g} / \mathrm{ml})$ (cod. P6556, Sigma Chemical) for $15 \mathrm{~min}$ at room temperature to strip proteins from nuclei and then rinsed in PBS. Endogenous peroxidase was inactivated by covering the sections with $2 \% \mathrm{H}_{2} \mathrm{O}_{2}$ in methanol for $30 \mathrm{~min}$ at room temperature. Sections were rinsed with PBS and incubated with terminal deoxynucleotidyl transferase (ApopTag ${ }^{\circledR}$ Plus Peroxidase In Situ Apoptosis
Detection Kit, cod. S7101, Chemicon International, Temecula, CA, USA) (Tdt enzyme 1: 12 reaction buffer) for $1 \mathrm{~h}$ at $37^{\circ} \mathrm{C}$. Sections were incubated with anti-digoxigenin conjugate for $30 \mathrm{~min}$ at room temperature. Color development was achieved by incubation for $6 \mathrm{~min}$ with $3,3^{\prime}$-diaminobenzidine tetrahydrochloride (DAB) 1: 1000 (brown) (cod. D5637, Sigma Chemical). Sections were then incubated with the antibody anticytokeratin 19 (mouse monoclonal antibody anti-cytokeratin 19 cod. NCLCK19, Novocastra Laboratory, Newcastle upon Tyne, UK) (1 : 1000) overnight, rinsed in PBS, and again incubated with the secondary antibody anti mouse/rabbit (Envision $^{\circledR}$ Labelled Polymer, AP Mouse/Rabbit cod. K4017, DAKO, Carpinteria, CA, USA) for $30 \mathrm{~min}$ at room temperature. The color development (dark blue) was achieved with Nitro blue tetrazolium chloride/5-bromo,4-chloro-3indoyl phosphate, toluidine salt (NBT/BCIP) (Roche Diagnostics, Penzberg, Germany, Cat. no. 1681451).

\section{Results}

The proximal arrector pili muscle insertion indicating the bulge level was identifiable in all transverse scalp biopsy specimens of cases and controls. The mean number of identifiable follicular units in cases was $9.2( \pm 1.1)$ and $9.8( \pm 1.1)$ in controls. There was an architectural disturbance of the perifollicular collagen bundles in cases when compared with controls. The mean number of follicles was slightly higher in cases $[23.7( \pm 7.1)]$ than that in control subjects $[20.5( \pm 3.0)]$. By classifying the follicles in terminals and velus, we observed a higher proportion of terminals follicles in cases $[95 \%( \pm 2 \%)]$ than that in controls $[80 \%( \pm 1 \%)]$. By contrast, the proportion of anagen follicles was lower in cases [91\% $( \pm 2 \%)]$ than that in controls $[96 \%( \pm 1 \%)]$. The proportion of catagen follicles was very similar in cases $2 \%( \pm 3 \%)$ and controls $2 \%( \pm 4 \%)$. The proportion of telogen follicles was higher in cases $[7 \%( \pm 6 \%)]$ than that in controls $[2 \%( \pm 12 \%)]$ (Fig. 1). The mean number of telogen germinal units and residual fibrous tracts was $0.7( \pm 0.7)$ and $0.1( \pm 0.4)$ in cases and $0.7( \pm 0.5)$ and $0.2( \pm 0.4)$ in controls, respectively (Table 1 ). No perifollicular inflammatory infiltration was found in cases and controls.

Double-staining (TUNEL/CK19) positive outer root sheath keratinocytes showed a dark blue cytoplasm and brown nucleus (Figs 2 and 3). Eighty percent of cases $(n=12)$ and $25 \%(n=3)$ of the controls presented TUNEL/CK19-positive cells in the outer root sheath at the bulge level. The proportion of positive follicles in each section in cases was 48\% 


\section{Stem cell apoptosis}

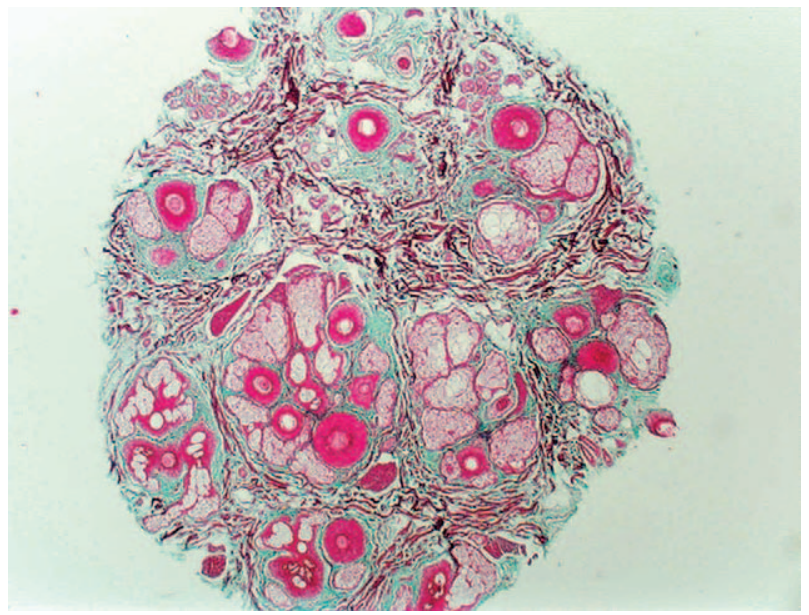

Fig. 1. Diffuse alopecia in HIV-1-positive patient. Scalp transverse section at the arrector pili muscle insertion level showing an increased number of telogen follicles and terminal germinal units. Gomori's trichromic stain. Original magnification, $\times 40$.

$( \pm 7 \%)$ and in controls $26 \%( \pm 13 \%)$ (Table 2$)$. There was no correlation between CD4 cell counts and the proportion of double-stained follicles. TUNELpositive/CK19-negative keratinocytes of the outer root sheath surrounding TUNEL/CK19-positive cells were seen in most part of cases and controls.

\section{Discussion}

Apoptosis of bulge cells was previously described in HIV-1-diffuse alopecia; ${ }^{4}$ however, its etiopathogenic mechanism is still unknown. There were no controlled studies demonstrating that bulge CK19-positive cells apoptosis occurs in a higher degree in HIV-1-infected patients than in normal subjects. Although stem cell apoptosis sounds paradox, it has been described in other self-renewing tissues under physiological conditions and is vital for remodeling the follicle and bulge during catagen. ${ }^{8}$

By using a molecular immunohistochemical technique, in transverse scalp samples, we were able to detect apoptosis in the bulge of follicles represented in both cases and controls. The proportion of positive results (at least one double-stained follicle per section) was $80 \%$ of cases and $25 \%$ of controls. The proportion of follicles presenting apoptotic (TUNEL/CK19 positive) cells in outer root sheath at the bulge, in each section, was also higher in HIV-1-infected patients $[48 \%( \pm 7 \%)]$ than that in normal controls $[26 \%( \pm 13 \%)]$, and it was not related to immunodeficiency state.

Even so, CK19 can be considered as a marker of undifferentiated keratinocytes in the bulge, it is not restricted to the stem cells, and it is also found in more differentiated transit amplifying cells that originate the secondary germ. ${ }^{16}$ In our study, we cannot be precise immunohistochemically that apoptosis was restricted to stem cell population.

No perifollicular inflammatory infiltrate was found in our study, making the possibility of a cytotoxic folliculitis (GVHD-like), as proposed by Smith et al. ${ }^{4}$, very unlikely. Furthermore, if the stem cell compartment had been damaged by a cytotoxic process, we might expect inflammation leading to scar formation and that is not the course of HIV-diffuse noncicatricial alopecia.

There was an architectural disorder of the perifollicular collagen bundles that was reflected in the lower number of identifiable follicular units in cases (Fig. 1). Comparing to control group, this result was not very different, but from a morphological viewpoint, it was noteworthy. Such structural alteration is more frequently found in cicatricial alopecias but can happen in late stages of non-cicatricial ones, as observed in alopecia areata. ${ }^{17}$ The higher number of telogen follicles seen in cases represents a hair follicle cycle disturbance, leading to a chronic diffuse telogen hair loss. This type of hair follicle cycle disturbance can happen in the course of this chronic infection, mainly in the late stages with a low number of CD4 cells.

Except for the protease inhibitor indinavir, there is no relation between any drug used in HAART and alopecia. The proposed pathologic mechanism for indinavir-induced alopecia is an alteration of the hair cycle induced by a disturbance on the retinoid metabolism, leading to a reversible loss of telogenic hairs. ${ }^{18}$ Retinoid-like side effects as cheilitis, dry skin, paronychia, lipodystrophy, and alopecia are expected in indinavir-treated patients because of the homologies between amino acids sequences of retinoic acid-binding protein 1 (RABP-1) and the catalytic site of HIV-1 protease, the target of protease inhibitors. ${ }^{18-20}$ However, indinavir-induced alopecia has no relation with other retinoid-like mucocutaneous manifestations, drug dosage, or CD4 cell counts, suggesting

Table 1. Histological morphometric analysis in diffuse non-cicatricial alopecia in HIV-1-positive patients and normal control group without alopecia

\begin{tabular}{|c|c|c|c|c|c|c|c|c|c|}
\hline Mean & $\begin{array}{l}\text { Follicular } \\
\text { units }\end{array}$ & $\begin{array}{l}\text { Total number } \\
\text { of follicles }\end{array}$ & $\begin{array}{l}\text { Terminal } \\
\text { follicles (\%) }\end{array}$ & $\begin{array}{l}\text { Vellus } \\
\text { follicles (\%) }\end{array}$ & $\begin{array}{l}\text { Anagen } \\
\text { follicles (\%) }\end{array}$ & $\begin{array}{l}\text { Catagen } \\
\text { follicles (\%) }\end{array}$ & $\begin{array}{l}\text { Telogen } \\
\text { follicles (\%) }\end{array}$ & $\begin{array}{l}\text { Terminal } \\
\text { germinal units }\end{array}$ & $\begin{array}{l}\text { Follicular } \\
\text { stela }\end{array}$ \\
\hline $\begin{array}{l}\text { Cases }(n=15) \\
\text { Controls }(n=12)\end{array}$ & $\begin{array}{l}9.2( \pm 1.1) \\
9.8( \pm 1.1)\end{array}$ & $\begin{array}{l}23.7( \pm 7.1) \\
20.5( \pm 3.0)\end{array}$ & $\begin{array}{l}95( \pm 2) \\
80( \pm 1)\end{array}$ & $\begin{aligned} 5( \pm 6) \\
20( \pm 4)\end{aligned}$ & $\begin{array}{l}91( \pm 2) \\
96( \pm 1)\end{array}$ & $\begin{array}{l}2( \pm 3) \\
2( \pm 4)\end{array}$ & $\begin{array}{l}7( \pm 6) \\
2( \pm 12)\end{array}$ & $\begin{array}{l}0.7( \pm 0.7) \\
0.7( \pm 0.5)\end{array}$ & $\begin{array}{l}0.1( \pm 0.4) \\
0.2( \pm 0.4)\end{array}$ \\
\hline
\end{tabular}




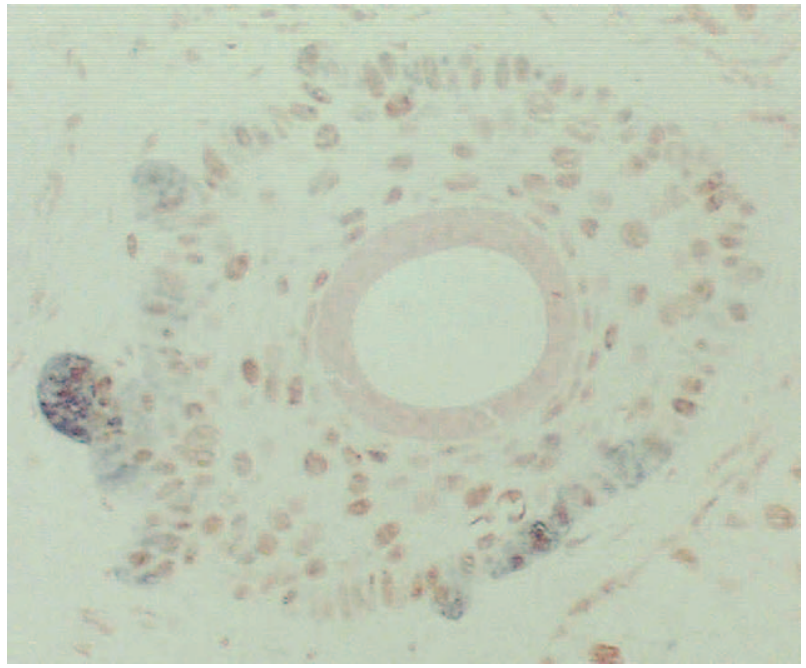

Fig. 2. Diffuse alopecia in HIV-1-positive patient. Horizontal section of a hair follicle at the bulge level, showing double-labeling TUNEL (DAB, brown)/CK19 (NBT/BCIP, dark blue)-positive cells in the outer root sheath. Original magnification, $\times 200$.

the possibility that this interference with the retinoid metabolism may not be sole pathogenic mechanism of this drug-induced alopecia. ${ }^{21}$ One of our cases had used indinavir for 6 months prior to biopsy. He presented no other mucocutaneous retinoid-like manifestations, and stem cell apoptosis was found in $82 \%$ of the follicles represented.

Apoptosis can be induced by the activation of death receptors (Fas, p55 TNF receptor, and TRAIL/APO $2-\mathrm{L}$ receptors land 2$)^{22-26}$ or by the mitochondrial pathway, ${ }^{23}$ both leading to caspase activation and proteolytic cleavage. There are many HIV-1mediated alterations in molecules that regulate apoptosis process, and there are virus proteins that are able to induce apoptosis of infected and uninfected cells,

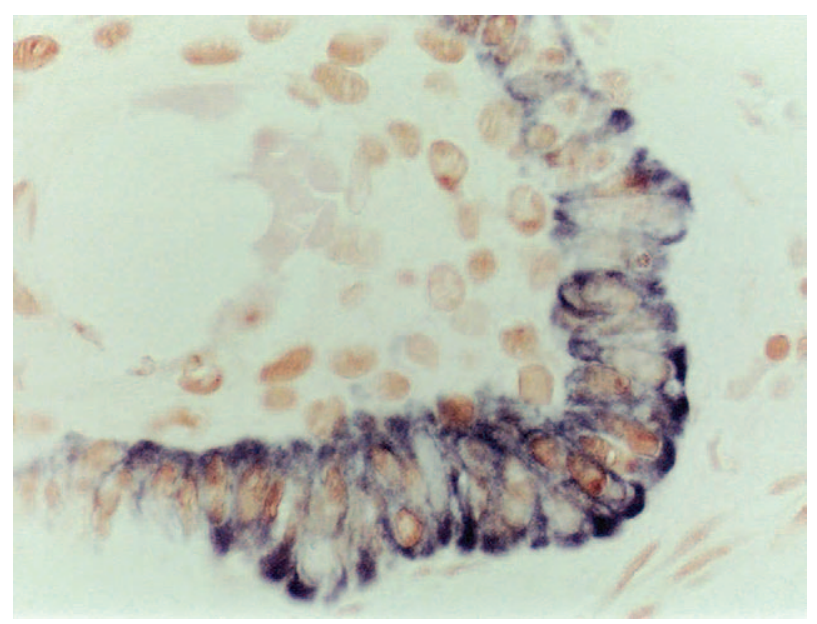

Fig. 3. Diffuse alopecia in HIV-1-positive patient. Note CK19-positive apoptotic cells in the outer root sheath, where follicular stem cells reside. CK19-negative cells labeled by TUNEL reaction are also observed. TUNEL (DAB, brown)/CK19 (NBT/BCIP, dark blue) double labeling. Original magnification, $\times 1000$.
Table 2. Apoptosis of follicular stem cells at the bulge in diffuse noncicatricial alopecia in HIV-1-positive patients and normal control group without alopecia

\begin{tabular}{lll}
\hline & $\begin{array}{l}\text { Positive results } \\
\text { (CK19/TUNEL- } \\
\text { positive cells } \\
\text { at the bulge) }(\%)\end{array}$ & $\begin{array}{l}\text { Double-stained } \\
\text { follicles per section } \\
\text { percentage }(\%)\end{array}$ \\
\hline Cases & 80 & $48( \pm 7)$ \\
Controls & 25 & $26( \pm 13)$ \\
\hline
\end{tabular}

mainly T lymphocytes. ${ }^{27}$ Among them, viral protein $\mathrm{R}(\mathrm{Vpr})$, a small (14 kDa) HIV-1 accessory protein, has many functions and acts as a chaperone. ${ }^{28,29}$ Vpr was initially related to the induction of rhabdomyosarcoma cell differentiation and was later related to induction of cell-cycle arrest at the G2/M phase of the cell cycle, and this arrest is followed by apoptosis. $^{28,29}$ Besides, HIV-1 Vpr is sufficient to induce caspase activation and apoptosis. ${ }^{30}$

In an attempt to explain the follicular stem cell apoptosis observed in diffuse alopecia of HIV-1infected patients, it is feasible that $\mathrm{Vpr}$ could induce a follicular stem cell cycle arrest in the G2/M phase that could be the cause of the catagen regression. The referred cell-cycle arrest could also lead to a telogen effluvium after the transient amplifying cells (secondary germ) in the bulb become postmitotic. In addition to that, after interaction with the mitochondrial membrane (increase Bax and decrease Bcl-2 expression), Vpr induces apoptosis of some cells. A similar mechanism has been observed in the pathogenesis of neuronal apoptosis induced by Tat protein in the context of the oxidative stress, with high levels of TNF- $\alpha$ in HIV-1 dementia. ${ }^{31}$

Although our study set is small, it demonstrated that diffuse alopecia found in HIV-1-infected patients represents a hair cycle interruption that manifests itself through an effluvium. The study also demonstrated that part of the follicular stem cell population becomes apoptotic in a greater extent than in normal subjects. In which extent follicular stem cell apoptosis is no more than a consequence of the catagen regression instead of the cause of this chronic diffuse telogen hair loss is to be evaluated. No cytotoxic folliculitis was found. Assuming that stem cell apoptosis plays a role in the pathogenesis of this alopecia, one should seek a soluble factor that could be responsible for apoptosis induction. Because of its cell-cycle interaction and caspase-induction capacities, ${ }^{28-30}$ we propose the HIV-1 protein Vpr as a possible answer.

\section{Acknowledgements}

This study was supported by a grant from CNPq (Conselho Nacional de Pesquisa) process 472715/2003-8 and 504726/ 2003-0 and CAPES (Coordenação de Aperfeiçoamento de Pessoal de Nível Superior). 


\section{Stem cell apoptosis}

\section{References}

1. Calista D, Morri M, Stagno A, Boschini A. Changing morbidity of cutaneous diseases in patients with HIV after the introduction of highly active antiretroviral therapy including a protease inhibitor. Am J Clin Dermatol 2002; 3: 59.

2. Wiwanitkit V. Prevalence of dermatological disorders in Thai HIV-infected patients correlated with different CD4 lymphocyte count statuses: a note on 120 cases. Int J Dermatol 2004; 43: 265 .

3. Calista D, Boschini A. Cutaneous side effects induced by indinavir. Eur J Dermatol 2000; 10: 292.

4. Smith KJ, Skelton HG, De Russo D, et al. Clinical and histological features of hair loss in patients with HIV-1 infection. J Am Acad Dermatol 1996; 34: 63.

5. Paus R, Muller-Rover S, van der Veen C, et al. A comprehensive guide for the recognition and classification of distinct stages of hair follicle morphogenesis. J Invest Dermatol 1999; 113: 523.

6. Muller-Rover S, Rossiter H, Lindner G, Peters E. Hair follicle apoptosis and Bcl-2. J Invest Dermatol 1999; 4: 272.

7. Cotsarelis G, Tung-Tien S, Lavker RM. Label retaining cells reside in the bulge area of pilosebaceous unit: implications for follicular stem cells, hair cycle and skin carcinogenesis. Cell 1990; 61: 1329 .

8. Ito M, Kizawa K, Iiamada K, Cotsarelis G. Hair follicle stem cells in the lower bulge from the secondary germ, a biochemically distinct but functionally equivalent progenitor cell population, at termination of catagen. Differentiation 2004; 72: 548 .

9. Ito M, Kizawa K, Toyoda M, Morohashi M. Label retaining cells in the bulge region are directed to cell death after plucking, followed by healing from the surviving hair germ. J Invest Dermatol 2002; 119: 1310.

10. Sale GE, Beauchamp MD, Akiyama M. Parafollicular bulges, but not hair bulb keratinocytes, are attacked in graft-versus-host disease of human skin. Bone Marrow Transplant 1994; 14: 411.

11. Murphy GF, Lavker RM, Whitaker D, Korngold R. Cytotoxic folliculitis in GvHD: evidence of follicular stem cell injury and recovery. J Cutan Pathol 1991; 18: 309.

12. Headington JT. Transverse microscopy anatomy of the human scalp. A basis for a morphometric approach to disorders of the hair follicle. Arch Dermatol 1984; 120: 449

13. Narisawa Y, Hashimoto K, Khoda H. Immunohistochemical demonstration of keratin 19 expression in isolated human hair follicles. J Invest Dermatol 1994; 103: 191.

14. Michel M, Torok N, Godbout MJ, et al. Keratin 19 as a biochemical marker of skin stem cells in vivo and in vitro: keratin 19 expressing cells are differentially localized in function of anatomic sites, and their number varies with donor age and culture stage. J Cell Sci 1996; 109: 1017.
15. Stasiak PC, Purkis PE, Leigh IM, et al. Keratin 19: predicted aminoacid sequence and broad tissue distribution suggest it evolved from keratinocyte keratins. J Invest Dermatol 1989; 92: 707 .

16. Christofidou-Solomidou M, Liu Y, Elder DE, Abelda S, Cotsarelis G. Human hair follicle bulge cells are biochemically distinct and possess an epithelial stem cell phenotype. J Investig Dermatol Symp Proc 1999; 4: 296.

17. Templeton SF, Santa Cruz DJ, Soloman AR. Alopecia: histologic diagnosis by transverse sections. Semin Diagn Pathol 1996; 2: 18.

18. Bouscarat F, Prevot M, Sophie M. Alopecia associated with indinavir therapy. N Eng J Med 1999; 341: 618.

19. Colebunders R, Bottieau E, de Mey I. Curly hair and lipodystrophy as a result of highly antiretroviral treatment? Arch Dermatol 2000; 136: 1064.

20. Harry TC, Mathews M, Salvary I. Indinavir use: associated reversible hair loss and mood disturbance. Int J STD AIDS 2000; 474: 6.

21. Ginarte M, Losada E, Prieto A, Lorenzo-Zuniga V. Generalized hair loss induced by indinavir plus ritonavir therapy. AIDS 2002; 1695: 96.

22. Nagata S. Apoptosis by death factor. Cell 1997; 88: 355.

23. Scaffidi C, Fulda S, Srinivasan A, et al. Two CD95 (APO-1/ Fas) signaling pathways. EMBO J 1998; 17: 1675.

24. Darnay BG, Aggarwal BB. Early events in TNF signaling: a story of associations and dissociations. J Leukoc Biol 1997; 61: 559.

25. Wiley SR, Schooley K, Smolak PJ, et al. Identification and characterization of a new member of the TNF family that induces apoptosis. Immunity 1995; 3: 673.

26. Soengas MS, Alarcon RM, Yoshida H, et al. Apaf-1 and caspase-9 in p53 dependent apoptosis and tumor inhibition. Science 1999; 284: 156.

27. Badley A, Pilon A, Landay A, Lynch D. Mechanisms of HIVassociated lymphocyte apoptosis. Blood 2000; 96: 2951.

28. Basañez G, Zimmerberg J. HIV and apoptosis: death and the mitochondrion. J Exp Med 2001; 193: 11.

29. Agostini I, Popov S, Li J, Dubrovsky L, Hao T, Bukrinsky M. Heat-shock protein 70 can replace viral protein R of HIV-1 during nuclear import of the viral preintegration complex. Exp Cell Res 2000; 259: 398.

30. Stewart SA, Poon B, Song JY, Chen IY. Human Immunodeficiency virus type $1 \mathrm{Vpr}$ induces apoptosis through caspase activation. J Virol 2000; 3105: 11.

31. Shi B, Raina J, Lorenzo A, Busciglio J, Gabuzda D. Neuronal apoptosis induced by Tat protein and TNF- $\alpha$ : potentiation of neurotoxicity mediated by oxidative stress and implications for HIV-1 dementia. J Neurovirol 1998; 4: 281. 